\title{
EVAPORATIVE LOSSES OF WATER BY BIRDS
}

\author{
William R. DAWSON \\ Division of Biological Sciences, University of Michigan, Ann Arbor, MI 48109. U.S.A.
}

(Received 6 July 1981)

\begin{abstract}
Birds lose water in evaporation from the respiratory tract and, in many species, through the skin. Anatomical arrangements in the nasal passages contribute to conservation of water and heat from the expired air in the absence of heat loads. However, most species still expend more water in evaporation than they produce in metabolism when either quiescent or vigorously active. Certain small birds, several of them associated with arid environments, represent exceptions to this and their more favorable situation appears in part to reflect an ability to curtail cutaneous water loss.

2. Birds typically resort to panting in dealing with substantial heat loads developing in hot environments or accumulated over bouts of activity. In a number of species this form of evaporative cooling is supplemented by gular fluttering

3. The ubiquitousness of active heat defense appears to reflect more the importance for birds of dealing with heat loads existing following flight or sustained running than any universal affinity for hot climates. Panting can be sustained for hours, despite progressive dehydration and, in some instances, hypocapnia and respiratory alkalosis. The prominent involvement of thermoreceptors in the spinal cord in its initiation is of considerable interest.
\end{abstract}

\section{INTRODUCTION}

High metabolic levels associated with endothermy, high body temperatures, and the respiratory demands imposed by flight would seem to encumber birds with extravagant rates of evaporative water loss. The facts that most species are diurnal and that the smaller ones seem far less prone than their mammalian counterparts to utilize shelter such as that afforded by underground burrows might be expected to exacerbate this problem in hot climates (Dawson \& Bartholomew, 1968). For the large number of species weighing less than approx $100 \mathrm{~g}$, initial measurements of evaporative water loss and estimates of metabolic rate based on an early allometric equation for birds (Brody, 1945) suggested that such loss tends to exceed metabolic production of water even at moderate temperatures (Bartholomew \& Dawson, 1953). Such a relation would, of course, make these small birds dependent on succulent food or drinking for attaining water balance.

Inevitably, the substantial growth of information on avian evaporative water loss over the past three decades has indicated a more complex set of relations than originally perceived. A variety of behavioral, anatomical and physiological factors have been recognized that serve to curtail evaporation in birds. The role of evaporative cooling in heat defense has become better appreciated, and its extent during flight more accurately assessed. Better information on the dependence of standard metabolic rate on body size and temperature has permitted improved assessment of the relation of evaporation to the metabolic production of water. Compartmentalization of the cutaneous and respiratory components of evaporative water loss has begun. Finally, understanding of such loss has been extended back into the prehatching phase of development, through extensive analysis of the properties of avian eggs affecting diffusion of water vapor and respiratory gases.
This review of avian evaporative water loss will attempt to summarize current understanding of this process and of adaptations affecting it in various species. Emphasis is placed upon data for adult birds, but some information is provided on individuals in the early phases of post hatching life. A recent symposium (Carey, 1980, and accompanying articles) can profitably be consulted for treatment of the water relations of the avian egg. Reviews over the past two decades of evaporative water loss in birds include those by Bartholomew and Cade (1963), Salt (1964), SchmidtNielsen (1964), Dawson \& Schmidt-Nielsen (1964), King \& Farner (1964), Dawson \& Bartholomew (1968), Richards (1970a), Dawson \& Hudson (1970), Bartholomew (1972), Lasiewski (1972), Calder \& King (1974), Dawson (1976, 1981). Calder \& King (1974) provide a useful consideration of physical factors governing evaporation in these animals.

\section{ROUTES OF EVAPORATIVE WATER LOSS}

The absence of sweat glands and the enclosure of the body in a layer of contour feathers have been taken as indications that birds lose only negligible amounts of water through the skin. This appears true for some birds at least; Schmidt-Nielsen et al. (1969) observed that cutaneous losses accounted for less than $2 \%$ of the total evaporative output by ostriches (Struthio camelus) at a $T_{2}$ of $40^{\circ} \mathrm{C}$. However, studies on other species indicate a substantial role for peripheral evaporation (Table 1). The relative extent of cutaneous losses can be even higher in young birds, judging by Bernstein's (1971) observations on young painted quail (Coturnix chinensis), which underwent $38-53 \%$ reductions in mass-specific cutaneous evaporative water loss over the first 4 weeks after hatching. In the Japanese quail (Coturnix coturnix), the decline in cutaneous water loss over the first 13 days after hatching appears directly related to increased thick- 
Table 1. Cutaneous evaporation in birds*

\begin{tabular}{|c|c|c|c|c|c|}
\hline Species & $\begin{array}{c}\text { Body } \\
\text { mass } \\
(\mathrm{g})\end{array}$ & $\begin{array}{c}T t \\
(\mathrm{C})\end{array}$ & $\begin{array}{c}\text { Total } \\
\text { evaporation } \\
(\mathrm{mg} / \mathrm{g} / \mathrm{hr})\end{array}$ & $\begin{array}{l}\text { Cutaneous } \\
\text { evaporation } \\
\text { as } \% \text { of total }\end{array}$ & Reference \\
\hline $\begin{array}{l}\text { Powphila castanotis } \\
\text { zebra finch }\end{array}$ & 12.5 & 30 & 8.9 & 63 & Bernstein, 1971 \\
\hline $\begin{array}{l}\text { Melopsittacus tmblutus } \\
\text { budgerygah }\end{array}$ & 31.6 & 30 & 9.0 & 59 & Bernstein, 1971 \\
\hline $\begin{array}{l}\text { Cotwmix chinensis } \\
\text { painted qual }\end{array}$ & 42.3 & 30 & 4.7 & 45 & Bernstein. 1971 \\
\hline $\begin{array}{l}\text { Ploceus cucullatus } \\
\text { sociable weaver }\end{array}$ & 42.6 & 30 & 6.7 & 51 & Bernstein, 1971 \\
\hline $\begin{array}{l}\text { Phalachopilas nutrallit } \\
\text { poor-will }\end{array}$ & 43.2 & 35 & 5.9 & 51 & Lasiewski et at. 1971 \\
\hline $\begin{array}{c}\text { Geococyx californiamus } \\
\text { greater roadrunner }\end{array}$ & 274.2 & 35 & 2.9 & 51 & Lasiewski et al. 1971 \\
\hline \multirow{4}{*}{$\begin{array}{l}\text { Columba livia } \\
\text { domestic pigeon }\end{array}$} & ca. 300 & 35 & 13.6 & 74 & Smith. 1969 \\
\hline & & $40 B$ & 5.9 & 84 & \\
\hline & & $43 B$ & 22.3 & 67 & \\
\hline & & $46 \mathrm{~B}$ & 29.8 & 28 & \\
\hline \multirow{6}{*}{$\begin{array}{l}\text { Rhea americuna } \\
\text { thea }\end{array}$} & 21.500 & 25 & $0.7 R$ & $75 \mathrm{R}$ & Taylor et al., 1971 \\
\hline & & 25 & $2,9 \mathrm{~A}$ & $18 \mathrm{~A}$ & \\
\hline & & 35 & $2.2 \mathrm{R}$ & $23 R$ & \\
\hline & & 35 & $3.4 \mathrm{~A}$ & $9 \mathrm{~A}$ & \\
\hline & & 43 & $4.3 \mathrm{~A}$ & $28 \mathbf{R}$ & \\
\hline & & 43 & $4.5 A$ & $11 \mathrm{~A}$ & \\
\hline $\begin{array}{l}\text { Stmahio camelus } \\
\text { ostrich }\end{array}$ & 88,000 & 40 & 2.2 & $<2$ & Schmidt-Nielsen of al. 1969 \\
\hline
\end{tabular}

* Values are exclusively for resting birds except for Rhea americana. Resting values for this species are identified by "R". Those for individuals studied over $20 \mathrm{~min}$ of running at $5 \mathrm{~km} / \mathrm{hr}$ followed by $40 \mathrm{~min}$ recovery are identified by " $A$ ". "B".

+ Temperature values refer to ambient temperature in most cases. Body temperatures are identified by

ness of the cornified layer of the epidermis (McNabb \& McNabb, 1977).

Cutaneous evaporation by birds under heat loading can contribute substantially to evaporative cooling (Table 1), particularly in environments or during activities fostering considerable air movement over the body (Smith, 1969). Rautenberg et al's (1980) study of behavioral thermoregulation by domestic pigeons provides further information on the possible importance of cutaneous water loss. At an ambient temperature of $50 \mathrm{C}$ and a wind speed of $1.5 \mathrm{~m} / \mathrm{sec}$, cutaneous and pulmonary evaporation served to dissipate $2 \cdots 3$ and $0.6-0.8 \mathrm{~mW} / \mathrm{g}$, respectively. The pulmonary values were achieved without panting. owing to the birds" use of instrumental cooling (see below). When cutaneous evaporation in hot environments was curtailed in domestic pigeons by use of a whole body plethysmograph, temperature regulation was impaired relative to that of free standing controls (Smith, 1972). The cornea appears to represent another extra-respiratory surface that contributes to evaporative heat loss under certain conditions (Kilgore et al., 1973; Kilgore et al., 1979; Bernstein et al., $1979 \mathrm{a}, \mathrm{b})$ particularly with the rapid air movement over them occurring during flight.

\section{EYAPORATIVE WATER LOSS IN THE ABSENCE OF HEAT LOADING}

\section{Introduction}

In birds studied while resting and fasting in the inactive $(\rho)$ phase of their daily cycle, the ambient temperature marking the upper boundary of the zone of thermal neutrality (the temperature interval over which normothermia is maintained with a basal rate of heat production) is a convenient reference point (Fig. 1). Above this temperature, evaporative water loss shows a marked thermal dependence that will be examined subsequently. Below the lower critical temperature, such loss changes only slowly with temperature (Fig. 2). This condition persists even at ambient temperatures below the lower critical temperature (Fig. 1), where metabolic rate varies inversely with temperature. We shall examine avian evaporative

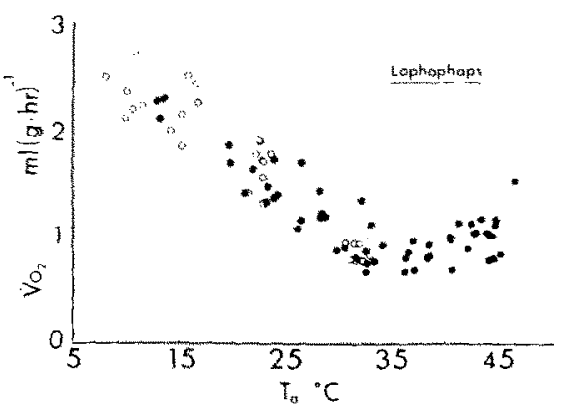

Fig. 1. Relation of nocturnal metabolic rate $\left(\dot{V} \mathrm{O}_{2}\right)$ to ambient temperature $\left(T_{\mathrm{a}}\right)$ for post absorptive western plumed pigeons resting in the dark. Shaded circles: Feb.-Mar. (austral. summer) determinations. Unshaded circles: May (austral. fall) determinations. The zone of thermal neutrality extends from approx 33 to $37^{\circ} \mathrm{C}$ (from Dawson \& Bennett, 1973). 
water loss in the absence of heat loads, paying particular attention to its impact upon the water budgets of birds.

\section{Factors serving to minimize evaporative water loss}

It would be advantageous for birds to minimize losses of heat and water from the respiratory tract under ambient conditions that do not require substantial evaporative cooling. They are assisted in this by capacities for oxygen extraction that allow substantially lower ventilation than in mammals of comparable size (see, e.g., Bernstein \& Schmidt-Nielsen, 1974; Bech \& Johansen, 1980a). Events occurring in the upper respiratory tract also contribute to conservation of water and heat when appropriate. As air is inspired it becomes heated nearly to body temperature and saturated with water vapor while still in the nasal passages. As heat is removed from the walls of these passages, their surface temperature falls below body temperature and they may become even cooler than the inhaled air. Expired air, essentially saturated with water vapor, leaves the lungs at body temperature. As it passes over the cool nasal surfaces. it is cooled and a portion of its water content condensed in the mucosa. Schmidt-Nielsen et al. (1970) have established that the recondensation is quantitatively important in a variety of birds. For example, at $15^{\circ} \mathrm{C}$ and $25 \%$ relative humidity, the cactus wren (Campylorhynchus brunneicapillum) recovered $74 \%$ and $75 \%$, respectively, of the water and heat added on inspiration. The heat conserved corresponds to $16^{\circ} \%$ of the metabolic heat production noted at $15^{\circ} \mathrm{C}$. This mechanism also operates in penguins (Pygoscelis spp.), reclaiming $>80 \%$ of the water and heat added to inspired air (Murrish, 1973). Schmidt-Nielsen et al. (1970) view the nasal passages of birds (and mammals as well) as countercurrent heat exchangers in which flow is separated in time, unlike the vascular heat exchangers found in the extremities of many aquatic animals in which the separation of flow is spatial. The action of the nasal passages is strikingly effective below the lower critical temperature in particular, where evaporative water loss tends to decline with decreasing temperature even though metabolic rate rises (see Figs 1 and 2).

Although heat storage and hyperthermia will be discussed more fully in connection with responses of birds to heat loading, it is important here to note briefly their occurrence below the upper critical temperature in resting

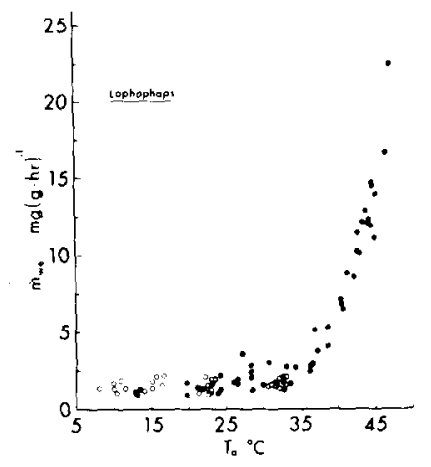

Fig. 2. Relation of nocturnal rate of evaporative water loss $\left(\dot{m}_{\mathrm{wc}}\right)$ to ambient temperature $\left(T_{\mathrm{a}}\right)$ for post absorptive western plumed pigeons resting in the dark at absolute humidities of 3-10 torr (aqueous vapor pressure). Measurements were made simultaneously with those on metabolism (Fig. 1). Shaded circles: Feb.-Mar. (austral summer) determinations. Unshaded circles: May (austral fall) determinations (from Dawson \& Bennett, 1973).

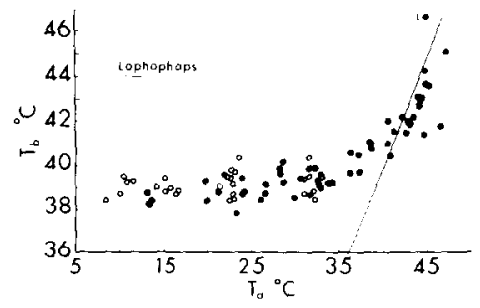

Fig. 3. Relation of body temperature $\left(T_{b}\right)$ at conclusion of metabolic tests (Fig. 1) to ambient temperature $\left(T_{\mathrm{a}}\right)$ in western plumed pigeons. Shaded circles: Feb.--Mar. (austral summer) determinations. Unshaded circles: May (austral fall) determinations. The one fatally high $T_{b}$ observed is identified by an "L" (from Dawson \& Bennet1, 1973).

and fasting individuals. As Weathers (1981) has established through analysis of results for several species, body temperature of birds under standard conditions tends to rise with ambient temperature in the upper portion of the zone of thermal neutrality (Fig. 3). Despite this, metabolic rate remains essentially at the basal level (cf. Figs 1 and 3). The rise in body temperature and the absence of a substantial Van't Hoff effect for metabolism serve to displace the upper critical temperature upward slightly, thereby deferring the onset of active evaporative cooling.

\section{Evaporative water losses of various species}

Variation in the humidities under which observations are made could hinder interspecific comparisons of total evaporative water losses $\left(\dot{m}_{\mathrm{we}}\right)$ of birds. However, Bernstein et al. (1977) found that $\dot{m}_{\text {we }}$ by pigeons at $20^{\circ} \mathrm{C}$ was independent of absolute humidity between vapor pressures of 3 and 8 torr. As will be discussed subsequently, this is not the case at high ambient temperatures. Presumably the situation at $20 \mathrm{C}$ involves adjustments of respiratory ventilation or temperature of the expired air in a manner serving to conserve both water and body heat.

Crawford \& Lasiewski (1968) have analyzed evaporative water losses of birds at $25 \mathrm{C}$ and obtained the following general equation:

$$
\dot{m}_{w e}=24.6 M^{0.585}
$$

where $\dot{m}_{\mathrm{we}}$ is total evaporative water loss in $\mathrm{g} / 24 \mathrm{hr}$ and $M$ is body mass in $\mathrm{kg}$. Water losses predicted with this equation for birds of various sizes are given in Table 2 . The rate of evaporation predicted for a $1 \mathrm{~kg}$ bird represents about $23 \%$ of the total daily output anticipated from measurements of tritiated water dilution (Ohmart et al., 1970). Evaporative water loss may vary with other factors than body mass. The loggerhead shrike (Lanius ludovicianus) shows a rate of pulmocutaneous evaporation approximately 1.5 times that anticipated for other passerines of comparable size ( $48 \mathrm{~g})$, a circumstance permitted by its succulent diet consisting of small vertebrates and insects (Cunningham, 1982).

Impact of evaporation on water budgets, with emphasis on small xerophilic birds

Since Bartholomew \& Dawson (1953) first pointed out that avian evaporative loss per gram varies inversely with body mass, perceptions of the impact of this function upon the water balance of birds in the absence of thermal loading have undergone some modification. Crawford \& Lasiewski's (1968) analysis indicated that the evaporative water loss in birds ranging from 3 to $100,000 \mathrm{~g}$ is proportional to $M^{0.59}$ (see equation 1), whereas basal metabolic rate varies with $M^{0.72}$ (Lasiewski \& Dawson, 1967). The shallower slope of the curve for evaporative water loss than 
Table 2. Predicted rates of evaporative water loss $\left(\dot{m}_{\text {we }}\right)$ at $25 \mathrm{C}$ for birds of various body masses*

\begin{tabular}{cccc}
\hline $\begin{array}{c}\text { Body mass } \\
(\mathrm{kg})\end{array}$ & $(\mathrm{g} / 24 \mathrm{hr})$ & $\begin{array}{c}\text { Predicted } \dot{m}_{\text {we }} \\
(\text { body mass } / 24 \mathrm{hr})\end{array}$ & $\begin{array}{c}\text { Predicted water } \\
\text { turnover } \\
(\mathrm{g} / 24 \mathrm{hr})\end{array}$ \\
\hline 0.003 & 0.8 & 27 & \\
0.01 & 1.7 & 17 & 21.4 \\
0.1 & 6.4 & 6 & 104.7 \\
1.0 & 24.6 & 2 & \\
10.0 & 94.6 & 0.9 & \\
100.0 & 363.9 & 0.3 & \\
\hline
\end{tabular}

* Predicted for unstressed birds with equation (1). It should be noted that $25^{\circ} \mathrm{C}$ will be below the lower critical temperatures, associated with the smaller body masses, whereas it will be within the zones of thermal neutrality associated with the larger ones. The figures on water turnover are calculated with the equation: total water loss $=104.7 M^{0.69}$, where the loss is in $\mathrm{g} / 24 \mathrm{hr}$ and $M$ body mass in $\mathrm{kg}$ (Ohmart et al., 1970). Only the two values are presented, as only 0.1 and $1.0 \mathrm{~kg}$ are in the range of body masses over which turnover was determined.

for metabolic rate in the absence of temperature stress fosters a tendency for the amount of water evaporated per unit of oxygen consumed to be greater in smaller birds than in larger ones (Bartholomew, 1972). Other things being equal, this should mean that less metabolic water should be produced relative to evaporation in the former animals. This relation is complicated by the fact that passcrine birds have basal metabolic rates about a third higher than those of non-passerine species of comparable size (Lasiewski \& Dawson, 1967). However, in the zone of thermal neutrality, birds of whatever taxonomic affinities generally lose more water in evaporation than they produce in metabolism and the discrepancy becomes greater as size decreases (see Bartholomew, 1972, for discussion). Practically speaking, this means that the evaporative water losses routinely exceed $0.67 \mathrm{mg} / \mathrm{ml}$ of oxygen consumed, the maximal value at which metabolic water could offset the loss (Schmidt-Nielsen, 1964). When water losses via urine and feces are added to those from evaporation, the situation is even less favorable, suggesting a broad requirement among birds for use of succulent food or drinking in maintaining water balance.

Exceptions do exist to the preceding generalization that birds must rely on drinking or use of succulent food in maintaining water balance. Species are known that can do so in the absence of heat stress while subsisting solely on seeds with a moisture content of approx $10 \%$ by mass. These birds are small (generally $<50$ g), have the relatively narrow zones of thermal neutrality and high lower critical temperatures typifying their size, and are for the most part xerophilic or associated with osmotically stressful situations such as salt marshes (Bartholomew, 1972). They include certain parrots (Cade \& Dybas, 1962; Lindgren. 1973), larks (Willoughby, 1968; Trost, 1972), and finches (Cade \& Bartholomew, 1959; Caider, 1964; Cade et al, 1965; Smyth \& Bartholomew, 1966; Willoughby \& Cade. 1967; Edmonds, 1968; Willoughby, 1969; Ohmart \& Smith, 1970, 1971; Lee \& Schmidt-Nielsen, 1971; Moldenhauer \& Taylor, 1973; Dawson et al., 1979). Their ability to contend successfully with water restriction depends upon abilities to reduce cloacal (Smyth \& Bartholomew, 1966: Willoughby, 1968; Dawson et al., 1979) and evaporative (Calder, 1964; Willoughby, 1968, 1969; Lee \& SchmidtNielsen, 1971; Dawson et al., 1979) water losses. The latter appears to depend exclusively on reduction of cutaneous losses, judging by Lee \& Schmidt-Nielsen's (1971) study of the zebra finch (Poephila gutrata). Just how this reduction is effected is unknown. The ability to maintain water balance during water restriction also depends importantly upon the favorable relation between the curtailed evaporative water loss and metabolic production of water that develops at moderate and cool temperatures. Under these conditions, the standard metabolic rate of such birds with their relatively high lower critical temperatures rises with decreasing ambient temperatures while evaporative water loss slowly declines (see Figs 1 and 2 for an illustration of this type of relation). Evaporative water loss evidently falls below $0.67 \mathrm{mg} / \mathrm{ml} \mathrm{O}_{2}$ consumed and thus can be offset by metabolic production of water. This is verified by observations on hydropenic zebra finches (Lee \& Schmidt-Nielsen, 1971) and Brewer's sparrows, Spizella breweri (Dawson et al.. 1979), in which pulmocutaneous water loss at $25^{\circ} \mathrm{C}$ amounts to 0.59 and $0.45 \mathrm{mg} / \mathrm{ml} \mathrm{O} \mathrm{O}_{2}$ consumed, respectively. The ability of the birds considered in this section to survive water restriction at cool and moderate temperatures appears to be a reserve capacity; all will readily use surface water and/or succulent food in nature even when heat is not a problem (Dawson, 1976). The main valuc of such a capacity may occur when they move between sources of surface water in the course of nomadic or migratory movements or when they encounter dry periods during the cooler parts of the year. It is doubtful that any bird preferentially refrains from drinking and utilizes a dry diet if water or succulent food is available (Dawson, 1976).

\section{Evaporatice cooling at temperatures below $38 \mathrm{C}$}

Calder \& King (1974) provide an analysis of the impact of evaporative water loss on the heat budget of birds, based on analysis of data for 20 species ranging in size from 6 to $100,000 \mathrm{~g}$. Between approx 1 and $38 \mathrm{C}$, the percentage of metabolic heat dissipated evaporatively under standard conditions increases exponentially from 7 to $45^{\circ}$, . The equation for this interval is:

$$
100\left(\dot{H}_{\mathrm{e}} / \dot{H}_{\mathrm{m}}\right)=5+1.48 \mathrm{e}^{0.087 T_{\mathrm{n}}}
$$

where $\dot{H}_{\mathrm{c}}$ and $\dot{H}_{\mathrm{m}}$ are evaporative cooling and metabolic heat production, respectively, expressed in the same units; $T_{\mathrm{a}}$ is ambient temperature in ${ }^{\circ} \mathrm{C}$ and $\mathrm{e}$ is the base of natural logarithms. It should be noted that evaporation will exceed metabolic production of water at percentages exceeding approx $8^{\circ}$. 


\section{EVAPORATIVE WATER LOSS UNDER HEAT LOADS RESULTING FROM EXERCISE AND/OR EXPOSURE TO HOT ENVIRONMENTS}

\section{Introduction}

The ubiquitousness of effective mechanisms for evaporative cooling among birds suggests that they may be more fundamentally linked with dissipating heat loads resulting from physical activity than with hot climates (Calder \& Schmidt-Nielsen, 1967). Whatever their origin, they can place a potentially severe drain on water resources. It therefore seems useful prior to reviewing the extent of evaporative cooling in birds, to consider some behavioral and physiological factors that lessen the demand for it.

\section{Behavioral mechanisms serving to minimize evaporation}

A diverse set of behavioral patterns serve to reduce demands for expenditure or water (see Table XV in Calder \& King, 1974). In hot climates, birds characteristically reduce activity in the middle of the day and seek the coolest microclimates available. This is seen even in domesticated birds; the Bedouin fowl (Gallus gallus) seeks shade during the middle of hot summer days in the Negev Desert and becomes prone in contact with the cooler soil (Marder, 1973a). In some birds retreat from the heat entails use of the shelter afforded by vegetation, as noted for Abert's Towhee (Pipilo aberti) in southeastern California (Dawson, 1954). Rock wrens (Salpinctes obsoletus) utilize the shelter provided by rocks in the deserts of southwestern United States (Smyth \& Bartholomew, 1966). Raptorial birds may employ a different strategy, soaring to great heights and cooler temperatures during the middle of the day as Madsen (1930) noted for hawks in the Sudan. Where surface water is available, some species may bathe in it, thereby effecting evaporation behaviorally rather than physiologically (Dawson \& Bartholomew, 1968). Wetting the plumage may also be important in allowing nesting birds to protect their eggs from overheating. For example, killdeer (Charadrius vociferus) on hot days crouched over their nests with wings slightly extended. Cooling of the eggs was enhanced by the adult's wetting its breast feathers before assuming incubation duty (Schardien \& Jackson, 1979).

The tendency of birds under heat loads to utilize behavioral options before initiating extensive evaporative cooling is well illustrated by domestic pigeons. These birds can be trained to perform an instrumental response that provides convective cooling during an environmental heat load (Schmidt \& Rautenberg, 1975; Richards, 1976). This is used enough to reduce greatly or eliminate the need for evaporative cooling at ambient temperatures as high as $58^{\circ} \mathrm{C}$ (Schmidt \& Rautenberg, 1975). Water deprivation enhances instrumental cooling at $55^{\circ} \mathrm{C}$. However, instrumental responses providing food or water lead to neglect of behavioral thermoregulation in fasted or hydropenic pigeons (Rautenberg et al.. 1980). Such thermoregulation thus seems affected by initial physiological state. Interestingly, the preference that normally fed and watered pigeons show for behavioral over physiological temperature regulation in warm environments is not seen in cool environments, where shivering and postural adjustments are clearly preferred over instrumental responses providing warming (Richards, 1976; Schmidt, 1978).

Physiological characteristics serving to reduce the demand for evaporative cooling

Birds show excellent capacities for adjusting heat transfer and they thereby can reduce substantially the requirements for evaporative cooling during exercise or exposure to warm environments, (i.e. ones in which a favor- able differential for non-evaporative heat loss exists between the animal's temperature and the operative temperature of its surroundings). A number of activities can contribute to this adjustment: compressing the contour plumage (Dawson, 1954), holding the wings away from the body so that the thinly feathered sides of the thorax are exposed (Dawson, 1954; Hutchinson, 1954; Bartholomew. 1966; Bartholomew et al., 1968; Marder, 1973a; Butler et al., 1977), elevating the scapular feathers in such a manner that convective heat loss is facilitated while a barrier to solar radiation is retained (Bartholomew, 1966: Bartholomew \& Dawson, 1979), increasing blood flow to the legs and feet (Bartholomew \& Dawson, 1954, 1958; Steen \& Steen, 1965; Bernstein, 1974), shading these structures while exposing them to air flow (Howell \& Bartholomew, 1961), and, in certain cases, increasing perfusion of combs or wattles (Yeates et al., 1941).

Heat dissipation becomes a more formidable problem during flight owing to as much as a 10 -fold increase in metabolic rate over resting values (Berger \& Hart, 1974). Non-evaporative heat dissipation appears to be allgmented in several ways. The thinly feathered sides of the thorax are exposed during movement of the wings (see, e.g., Tucker, 1968). The rate of heat loss through the contour plumage itself appears to be increased 5-7-fold in flying birds, judging from results obtained with heat flow discs implanted subcutaneously over the pectoral muscles of pigeons which were allowed to fly at $6-17.5^{\circ} \mathrm{C}$ (Hart \& Roy, 1967). Blood flow to the webbed feet of herring gulls (Larus argentatus) is increased to approx 3.5 times resting values during flights at $20.2-28.6^{\circ} \mathrm{C}$. This results in dissipation of $46 \mathrm{~W}$ in these birds, $80 \%$ of the estimated heat production during flight (Baudinette et al., 1976). Even when the feet are not webbed, they appear to serve as important sites of heat loss during flight. Tucker (1968) describes the tendency of budgerigars (Melopsittacus undulatus) flying at $37^{\circ} \mathrm{C}$ to extend their feet into the slipstream. Coupled with the increased rates of air movement over the body in flight, these activities contribute to the substantial increase in the heat transfer coefficient noted in flying birds such as the budgerigar, in which this coefficient increases approx 5-fold (Tucker, 1968).

Birds tolerate hyperthermia up to or slightly exceeding $46 \mathrm{C}$ withuat appatent ill effect (see, e.g., Taylor et at., 1971; Kilgore et al., 1973; Torre-Bueno, 1976). This tolerance of elevations of up to $4-6^{\circ} \mathrm{C}$ (cf. normothermic values provided by Neumann et al, 1968) appears of considerable functional significance, for these animals at rest almost universally store heat during exposure to hot environments (Bartholomew, 1964; Dawson \& Schmidt-Nielsen, 1964: Dawson \& Bartholomew, 1968; Dawson \& Hudson. 1970). The ostrich ordinarily represents an exception. However, it resorts to hyperthermia when dehydrated (Crawford \& Schmidt-Nielsen, 1967). Hyperthermia appears as though it could reduce demand for evaporative cooling in warm environments by either improving capacity for non-evaporative heat dissipation when the operative temperature of the environment is below body temperature, or by reducing heat gain when it exceeds $T_{\mathrm{b}}$. The opportunity also exists for reducing evaporative water loss further by deferring dissipation of stored heat until it can be accomplished nonevaporatively during the cooler night-time hours. Calder \& King (1974) conclude that hyperthermia is advantageous to all birds in hot environments. However, the importance to water economy attendant upon elevated body temperature varies directly with body size $\left(M^{0.28}\right)$, whereas the significance of the reduced thermal gradient for heat loading is inversely related to size $\left(M^{-0.27}\right)$.

Many birds also store heat during running (Taylor et $a l$., 1971) or flying (Farner, 1956: Howell \& Bartholomew, 1962; Hart \& Roy, 1967; Berger et al., 1971; Aulie, 1971; Baudinette et al., 1976; Torre-Bueno, 1976; Butler et al., 1977; Bernstein et al., 1979b; Butler \& Woakes. 1980), par- 
ticularly when the activity takes place in warm environments (Tucker, 1968; Taylor et al., 1971; Torre-Bueno, 1976: Hudson \& Bernstein, 1981). Body temperatures in flight are as much as $4 \% \mathrm{C}$ higher than at rest and appear independent of $T_{\mathrm{i}}$ in cool and moderate environments (Torre-Bueno, 1976; Hudson \& Bernstein, 1981), insulation apparently being adjusted to establish and maintain the particular temperature elevation. Torre-Bueno (1976) suggests that the primary role of this type of hyperthermia is to provide thermal conditions within the tissues, which serve to enhance capacities for physical exertion. Conservation of water by storage of heat is regarded as being of secondary importance. However, at high ambient temperatures, the same considerations outlined for resting birds would apply. This latter circumstance is well illustrated by analysis of the performance of the rhea (Taylor et al., 1971). Three-quarters of the heat produced by this bird while running for $20 \mathrm{~min}$ at $10 \mathrm{~km} / \mathrm{hr}$ and $43^{\circ} \mathrm{C}\left(T_{i}\right)$ was stored and body temperature exceeded $45^{\circ} \mathrm{C}$. In resting rheas, in which body temperature rose only slightly above $40^{\circ} \mathrm{C}$ with a $1 \mathrm{hr}$ exposure to $43^{\circ} \mathrm{C}$, hcat amounting to $60^{\circ} \%$ of metabolic heat production was gained from the environment. In contrast, running individuals, which became heated to above $45 \mathrm{C}$, gained virtually no heat from their surroundings (Taylor ef al., 1971). The situation in birds flying in hot environments appears less stable. When flying at $37^{\circ} \mathrm{C}$ $\left(T_{i}\right)$ the budgerigar stored $13 \%$ of its heat production, producing a rise in body temperature of $0.2 \mathrm{C} / \mathrm{min}$. The bird could not be made to fly more at $37^{\circ} \mathrm{C}$ once its body temperature reached $44^{\circ} \mathrm{C}$. Starlings (Sturnus vulgaris) showed similar reluctance to fly at $35^{\circ} \mathrm{C}$, presumably because of an inability to achieve heat balance (TorreBueno, 1976).

\section{Brain cs core temperature}

The ability of birds to resort successfully to heat storage during exercise and exposure to hot environments is undoubtedly aided by a mechanism that maintains the temperature of the brain somewhat below that of the body core. Most birds thus far studied (Richards, 1970b; Scott \& van Tienhoven, 1971; Kilgore et al, 1973, 1976; Bernstein et at. 1979a) can maintain the temperature of the anterior hypothalamus approx $1 \mathrm{C}$ cooler than the body core over a range of cloacal and ambient temperatures. All of these animals possess well developed retia mirabile ophthalmica in the temporal regions of the skull. The retia consist of multiple branches of the external ophthalmic artery which lie in intimate contact with a venous network whose afferent vessels originate in the orbit and buccopharyngeal cavity (Wingstrand \& Munk, 1965; Richards, 1970b: Kil. gore $t$ t al., 1973, 1976). These vascular arrangements strongly suggest that the retia act as countercurrent heat exchangers, permitting warm blood flowing toward the brain to lose heat to the cooler venous blood returning from the evaporative surfaces of the head. As noted previously, these surfaces appear to include the cornea (Bernstein et al. 1979a.b) as well as those associated with the anterior respiratory tract. The anatomical indications that the retia function as effective countercurrent heat exchangers for the brain are supported by physiological observations (Kilgore et al., 1979; Bernstein et al., 1979b).

\section{Control mechanisms governing active evaporative cooling}

Physiological factors affecting cutaneous evaporation of birds are not well understood. Thus knowledge concerning mechanisms serving to increase evaporative cooling in response to heat loads produced by exercise or exposure to hot environments is mainly confined to the respiratory system. As Lasiewski (1972) notes, all birds thus far studied respond to substantial heat loads by increasing respiratory frequency and opening the mouth. Tidal volume generally appears to be reduced, sometimes to a value matching the dead space of the system (Bech \& Johansen, 1980b). The internal threshold for this panting response lies between 41 and $44^{\circ} \mathrm{C}$ (King \& Farner, 1964). Panting is supplemented in birds of several orders (see Dawson \& Hudson, 1970) by gular fluttering, a rapid vibration of the membranous gular region, which is driven by the hyoid apparatus. Much of the information concerning neural control of these activities has been reviewed by Richards (1970a, 1975), Lasiewski (1972), Calder \& King (1974), and Richards \& Avery (1978). whose articles should be consulted. With respect to heat defense and particularly panting, this control displays several features, some of which differ from those in mam. mals. The anterior hypothalamic/preoptic area contains warmth receptors comparable in sensitivity to those found in mammals (Simon et al., 1977). However, the area exerts a weaker control on heat defense than is the case in mammals (Simon-Oppermann et al., 1978), and it operates in conjunction with deep body and peripheral temperature receptors (Richards, 1970b, 1971a, 1975: Richards \& Avery, 1978). Many or all of the former lie within the spinal cord (Rautenberg, 1969; Rautenberg et al., 1978), where examples have been directly demonstrated (Necker, 1975). Spinal thermosensitivity persists in pigeons even after spinal deafferentation (Necker \& Rautenberg, 1975). Warming the rostral brain stem or spinal cord will lead properly trained domestic pigeons to initiate the behaviotal responses producing cooling (Schmidt, 1976) which have been described earlier. Selective heating of the vertebral column can elicit panting without any change in hypothalamic temperature. At $27-30^{\circ} \mathrm{C}\left(T_{\mathrm{a}}\right)$ selective heating of the spinal cord evokes thermal panting and vasodilation of the feet. On the other hand, cooling of the spinal cord of animals panting at $36-37^{\circ} \mathrm{C}\left(T_{3}\right)$ lowers respiratory frequency to resting values (Rautenberg. 1969). Experimental manipulation of both skin and spinal cord temperatures provides evidence of a proportional control system in which the thermal set point for the spinal cord can be modified by changes in skin temperature (Rautenberg. 1971). Manipulation of temperatures of both the brain stem and spinal cord provides further indication of the importance of the latter region in thermoregulation. Selective heating of the brain stem to $44 \mathrm{C}$ seldom produces panting in pigeons, whereas heating the spinal cord to $42-43^{\circ} \mathrm{C}$ generally results in polypnea under thermoneutral conditions. In hot environments, heating the spinal cord and cooling the brain stem inhibit panting in only a quarter of the cases. On the other hand, cooling the spinal cord often inhibits panting (Rautenberg et al,, 1972). Signals generated in the brain stem of the pigeon seem primarily to affect ptilomotor and vasomotor activities serving to stabilize body temperature under mild thermal loads. Under more severe heat stress, heating of the spinal cord serves to activate panting. The preoptic area appears to function as a center of integration of temperature signals in the thermoregulatory system (Rautenberg et al, 1978), In pigeons, this area includes neurons whose activity is influenced by thermal stimulation of the spinal cord (Rosner, 1975). Perhaps the important role of extracranial receptors in heat defense is linked with the elaborate vascular arrangements for cooling the hypothalamic area described previously.

The control of panting in birds also has other features. An area in the dorsal midbrain, which was first described by von Saalfeld (1936), functions as a panting center which Richards (1971b) suggests as a possible avian counterpart of the mammalian pneumataxic center. This midbrain area is the dominant frequency controller in panting (Richards \& Avery, 1978). The vagal afferent system also seems prominently involved in panting. Sectioning of one vagus during hyperthermia reduced respiration frequency in the domestic pigeon, domestic fowl, Japanese quail, and duck (Anas platyrhynchos). Bilateral vagotomy had little further effect in the panting pigeon but abolished rapid respiration in the other three birds. Appropriate afferent stimulation of 
the vagi in vagotomized fowl maintained normal respiration or thermal panting. Of the four species studied, the pigeon seems least reliant on vagal stimulation for production of a panting response (Richards, 1968).

Despite the obvious importance of peripheral thermoreception in avian temperature regulation, relatively little is known of the units involved. Richards (1975) and Dawson (1975) cite some examples of peripheral warmth receptors in birds.

\section{Patterns of actite heat defense}

Lasiewski (1972) has identified several patterns by which evaporative cooling of birds is augmented in response to heat loads (Table 3). The extent to which evaporative cooling can beneficially affect the heat budgets of birds operating under heat loads is in part determined by the heat production associated with this process. The metabolic cost of panting and, in certain cases, gular flutter would be minimized if the oscillations of the thorax and hyoid apparatus were to occur at their respective resonant frequencies in the manner documented for panting in dogs (Crawford, 1962). The use of panting and, particularly, flutter frequencies occupying a narrow range and relatively independent of heat load (e.g. in panting by ostriches, gular flutter by poor-wills, and panting and gular flutter by pigeons [see Tables 3 and 4]) is suggestive of such an arrangement in certain birds. Calder \& King (1974) discuss an unpublished allometric analysis concerning the mass dependence of respiratory frequency in resting and panting birds, which they believe indicates an underlying relationship to mechanical efficiency that would be afforded by oscillation at a natural resonant frequency. However Lacey (1965) and Lacey \& Burger (1972) tested and rejected the hypothesis that panting of the domestic fowl proceeds at the resonant frequency of the thorax-lung system. Crawford \& Kampe (1971) do provide evidence that pigeons abruptly change from rest to panting at the rcsonant frequency of the respiratory system. However. Weathers (1972) noted transition from resting respiration to synchronized panting and gular flutter in pigeons during a gradual rise in ambient temperature. Smith (1969) likewise reported a gradual increase in panting frequency of pigeons in a whole body plethysmograph, which Calder \& King (1974) feel might be an artifact arising from constriction of the gular area in the collar of the apparatus. The surfaces from which evaporation occurs during panting and gular fluttering are discussed by Lasiewski (1972). For panting, these include the nasal, buccal, and upper pharnygeal regions, as well as the trachea. The air sacs may be involved in ostriches (Schmidt-Nielsen et al., 1969), but Menuam and Richards" (1975) observation indicate that they do not contribute to evaporative water loss during panting by the domestic fowl. Gular futtering leads to enhancement of evaporation from the moist surfaces of the pharynx and anterior esophagus, as well as those of the buccal cavity. These surfaces may be several degrees cooler than the body core (see, for example, Lasiewski \& Snyder, 1969), allowing them to act as a sink for heat ultimately produced in the brain or other tissues. This, of course, makes them subject to convective heat gain if the air passing over them is at a temperature approximating or exceeding core temperature (Seymour, 1972).

Evaporative water loss and effecticeness of exaporative cooling in hot environments

Evaporative water loss by birds has generally been measured in open circuit metabolism systems. For minimally realistic appraisal of evaporative water loss in hot environments, it is crucial that rates of air flow through such systems be high enough to maintain appropriately low atmospheric humidities. Lasiewski et al. (1966a) have provided a useful background for such studies. The linear rate of air movement through metabolism systems tends to be low and this may curtail cutaneous evaporation, resulting in underestimation of evaporative capacities (Smith, 1969)

The thermal dependence of evaporative water loss above the upper critical temperature is illustrated for the western plumed pigeon (Lophophaps ferruginea) in Fig. 2. The rise in the rate of this function with ambient temperatures above thermal neutrality appears primarily linked with increased movement of air over the mucosal surface of the mouth and other structures referred to previously. However, one should not ignore the probable contribution of cutaneous water loss, which can represent $67^{\circ}$ of the evaporative output of this substance by the domestic pigeon under a heat load producing a body temperature of $43^{\circ} \mathrm{C}$ (Table 1). The respiratory movements producing the increased ventilation of the mucosal surfaces culminate in panting and gular flutter with sufficient heat loading of birds. Calder \& King (1974) have assembled information on evaporative water losses of various birds at ambient temperatures exceeding body temperature. The rates under these conditions appear to approximate the maximal ones for these birds. The following allometric equation relates them to body size:

$$
\dot{m}_{\mathrm{we}_{\mathrm{m} n_{\mathrm{x}}}}=258.6 \mathrm{M}^{0.80}
$$

where $\dot{m}_{\text {we } \text { in }}$ is the maximal evaporative water loss in $\mathrm{mg} / \mathrm{min}$ and $M$ is body mass in $\mathrm{kg}$. The exponent in this equation is greater than that in equation (1), which becomes $\dot{m}_{\mathrm{we}}=17.1 M^{0.585}$, when $\dot{m}_{\mathrm{we}}$ is expressed in $\mathrm{mg} / \mathrm{min}$. The difference in exponents means that the factor by which maximal evaporative water loss exceeds $\dot{m}_{\text {we }}$ at $25^{\circ} \mathrm{C}$ will vary directly with body size (Table 5). Unfortunately, estimates of this factor obtained by use of equations (1) and (3) seriously misestimate actual values for some species (Table 5). Clearly, further analysis of evaporative capacities of birds is needed.

The rates of evaporative water loss by birds under stress that have been discussed thus far represent integrated values that provide little information concerning the manner in which birds manage their evaporative cooling minute by minute. A better view of this is afforded by Lasiewski's (1969) study of a $45.9 \mathrm{~g}$ poor-will (Phalaenoptilus nuttalii) whose evaporative water loss was monitored continuously by direct weighting with a recording balance. When not gular fluttering, the bird evaporated $3.4 \mathrm{mg}$ $\mathrm{H}_{2} \mathrm{O} / \mathrm{min}$, a rate independent of ambient temperature. The amount of water evaporated during gular flutter increased linearly at the rate of $1.3(\mathrm{mg} / \mathrm{min} / \mathrm{C})$ with ambient temperatures between 36 and $50^{\circ} \mathrm{C}$. Rates of evaporation wcre correlated with the proportion of time gular flutter was utilized, flutter amplitude, and size of the area moved during flutter. Lasiewski (1969) viewed gular flutter of the poor-will as a graded on-off system, capable of accounting for more than half of the evaporative cooling required under severe heat stress with very little metabolic cost; oxygen consumption of a poor-will at $47^{\circ} \mathrm{C}$, where fluttering was nearly continuous. was only $13 \%$ higher than at $35^{\circ} \mathrm{C}$, whereas evaporative water loss had increased by more than $750 \%$. Not all species show this level of effectiveness. Weathers and Schoenbaechler (1976) have determined that gular flutter of Japanese quail accounts for $20^{\circ}$. of evaporative cooling above $40 \mathrm{C}\left(T_{3}\right)$.

The proportion of metabolic heat dissipated evaporatively at various temperatures by several species is summarized in Table 6. Performance of most at the highest temperatures ranges between 100 and $200 \%$, though some, e.g. the poor-will and spotted nightjar (Eurostopodus guttatus), can do substantially better than this. However, this ability may be as importantly influenced by metabolic level as evaporative capacity, judging from an analysis provided by Lasiewski \& Seymour (1972). They compared birds of four species, each weighing approx $40 \mathrm{~g}$. The sociable weaver bird (Ploceus cucullatus) with the high metabolic level 


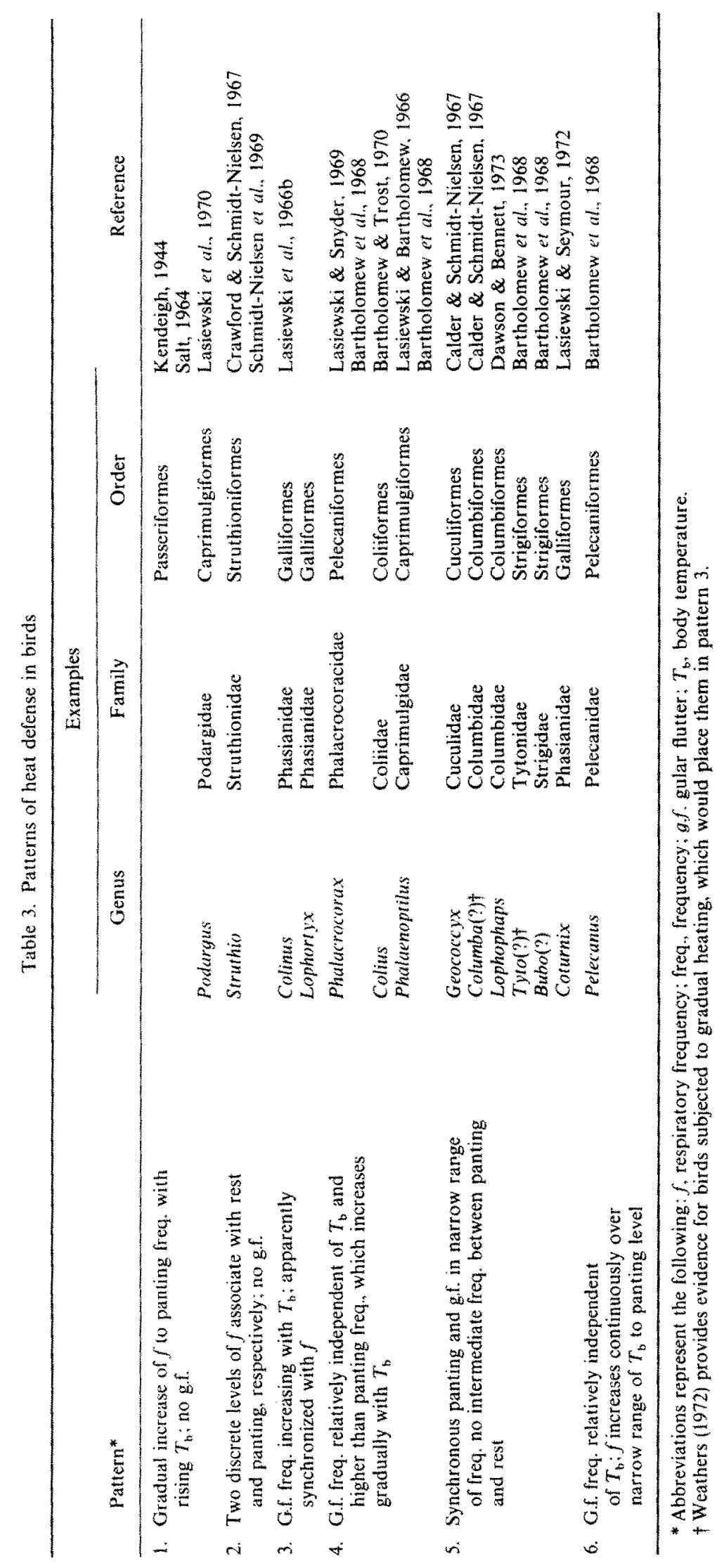


Table 4. Frequencies of respiration $(f)$ and gular flutter in panting birds

\begin{tabular}{|c|c|c|c|}
\hline Species & $\underset{(\text { cycles } / \mathrm{min})}{f}$ & $\begin{array}{c}\text { Gular } \\
\text { flutter } \\
\text { (cycles } / \text { min) }\end{array}$ & Reference \\
\hline $\begin{array}{l}\text { Pelecanus occidentalis } \\
\text { brown pelican }\end{array}$ & ca. $135^{*}$ & $239-290 \dagger$ & Bartholomew et al., 1968 \\
\hline $\begin{array}{l}\text { Phalacrocorax auritus } \\
\text { double-crested cormorant }\end{array}$ & $20-60$ & $645-730$ & Bartholomew et al., 1968 \\
\hline $\begin{array}{l}\text { Bubulcus ibis } \\
\text { cattle egret }\end{array}$ & $44-100$ & $860-1000$ & Hudson et al., 1974 \\
\hline $\begin{array}{l}\text { Lophortyx gambelii } \\
\text { Gambel's quail }\end{array}$ & & $70-700$ & Lasiewski et al., 1966b \\
\hline $\begin{array}{l}\text { Lophophaps ferruginea } \\
\text { western plumed pigeon }\end{array}$ & & $565-750$ & Dawson \& Bennett, 1973 \\
\hline $\begin{array}{l}\text { Columba livia } \\
\text { domestic pigeon }\end{array}$ & $650( \pm 60)$ & $650( \pm 60)^{\dagger}$ & Calder \& Smidt-Nielsen, 1967 \\
\hline $\begin{array}{l}\text { Geococcyx californianus } \\
\text { greater roadrunner }\end{array}$ & $356( \pm 58)$ & $356( \pm 58) \dagger$ & Calder \& Schmidt-Nielsen, 1967 \\
\hline $\begin{array}{l}\text { Tyto alba } \\
\text { barn owl }\end{array}$ & $245-285$ & $245-285$ & Bartholomew et al., 1968 \\
\hline $\begin{array}{l}\text { Bubo virginianus } \\
\text { great horned owl }\end{array}$ & $240-255$ & $210-255 \dagger$ & Bartholomew et al., 1968 \\
\hline $\begin{array}{l}\text { Phalaenoptilus nuttallit } \\
\text { poor-will }\end{array}$ & & $590-690+$ & Lasiewski \& Bartholomew, 1966 \\
\hline $\begin{array}{l}\text { Colius striatus } \\
\text { speckled mouse bird }\end{array}$ & & $510-610+$ & Bartholomew \& Trost, 1970 \\
\hline
\end{tabular}

* Approximate rate for body temperatures exceeding $41^{\circ} \mathrm{C}$. Between 40.2 and $41^{\circ} \mathrm{C}, f$ increases from 9 to 100 cycles/min.

+ Rate appears essentially independent of heat load.

characteristic of passerines, must evaporate considerably more water during heat stress to dissipate a given percentage of its metabolic heat production than would be required of the non-passerine doves and quail. The poorwill can evaporate the least amount of water in achieving this percentage owing to the very low metabolic level characterizing it and other members of the family Caprimulgidae (Bartholomew et al., 1962; Lasiewski \& Dawson, 1964; Dawson \& Fisher, 1969; Lasiewski \& Seymour, 1972). Regarding water balance, it should be remembered that evaporative cooling at rates equivalent to 100 and
$200 \%$ of metabolic rate results in factors of 12.4 and 24.8 for the extent to which evaporation exceeds metabolic production of water.

The details of panting responses

Normal panting by birds entails a large increase in respiratory frequency $(f)$ as well as a decline in tidal volume $\left(V_{\mathrm{T}}\right)$ over resting values in the absence of heat stress (Table 7). The increase in $f$ is sufficient to produce the increased ventilation $(\dot{V})$ serving to enhance evaporative loss of water (Table 6). Bech \& Johansen (1980b) note the

Table 5. Predicted* and observed factors by which maximum evaporative water loss $\left(\dot{m}_{w_{\text {mex }}}\right)$ exceeds $\dot{m}_{\text {we }}$ at $25^{\circ} \mathrm{C}$

\begin{tabular}{|c|c|c|c|c|c|c|}
\hline Species & $\begin{array}{c}\text { Body } \\
\text { mass } \\
(\mathrm{kg})\end{array}$ & $\begin{array}{c}\dot{m}_{w e} \\
\text { at } 25^{\circ} \mathrm{C} \\
(\mathrm{mg} / \mathrm{min})\end{array}$ & $\begin{array}{c}\text { Max. } \\
\dot{m}_{\text {we }_{\max }} \\
(\mathrm{mg} / \min )\end{array}$ & $a / b$ & $M / P$ & Reference \\
\hline $\begin{array}{l}\text { Poephila guttata } \\
\text { zebra finch }\end{array}$ & 0.012 & $\begin{array}{l}2.4 \mathrm{M} \\
1.3 \mathrm{P}\end{array}$ & $\begin{array}{c}10.2 \mathrm{M} \\
7.5 \mathrm{P}\end{array}$ & $\begin{array}{l}4.2 \mathrm{M} \\
5.8 \mathrm{P}\end{array}$ & 0.72 & Calder, 1964 \\
\hline $\begin{array}{l}\text { Lophophaps ferruginea } \\
\text { western plumed pigeon }\end{array}$ & 0.081 & $\begin{array}{l}2.6 \mathrm{M} \\
3.9 \mathrm{P}\end{array}$ & $\begin{array}{l}30.2 \mathrm{M} \\
34.6 \mathrm{P}\end{array}$ & $\begin{array}{c}11.6 \mathrm{M} \\
8.9 \mathrm{P}\end{array}$ & 1.31 & Dawson \& Bennett, 1973 \\
\hline $\begin{array}{l}\text { Eurostopodus guttatus } \\
\text { spotted nightjar }\end{array}$ & 0.088 & $\begin{array}{l}1.9 \mathrm{M} \\
4.1 \mathrm{P}\end{array}$ & $\begin{array}{l}40 \mathrm{M} \\
37.0 \mathrm{P}\end{array}$ & $\begin{array}{c}21.0 \mathrm{M} \\
9.0 \mathrm{P}\end{array}$ & 2.34 & Dawson \& Fisher, 1969 \\
\hline $\begin{array}{c}\text { Geococcyx californianus } \\
\text { greater roadrunner }\end{array}$ & 0.285 & $\begin{array}{l}7.1 \mathrm{M} \\
8.2 \mathrm{P}\end{array}$ & $\begin{array}{l}62.7 \mathrm{M} \\
94.7 \mathrm{P}\end{array}$ & $\begin{array}{l}8.8 \mathrm{M} \\
11.5 \mathrm{P}\end{array}$ & 0.77 & $\begin{array}{l}\text { Calder \& Schmidt- } \\
\text { Nielsen, } 1967\end{array}$ \\
\hline $\begin{array}{l}\text { Columba livia } \\
\text { domestic pigeon }\end{array}$ & 0.359 & $\begin{array}{l}8.9 \mathrm{M} \\
9.4 \mathrm{P}\end{array}$ & $\begin{array}{l}135.0 \mathrm{M} \\
113.9 \mathrm{P}\end{array}$ & $\begin{array}{l}15.2 \mathrm{M} \\
12.1 \mathrm{P}\end{array}$ & 1.25 & $\begin{array}{l}\text { Calder \& Schmidt- } \\
\quad \text { Nielsen, } 1967\end{array}$ \\
\hline $\begin{array}{l}\text { Corvus corax } \\
\text { raven }\end{array}$ & 0.610 & $\begin{array}{l}32.0 \mathrm{M} \dagger \\
12.8 \mathrm{P}\end{array}$ & $\begin{array}{l}297.4 \mathrm{M} \\
174.1 \mathrm{P}\end{array}$ & $\begin{array}{l}9.3 \mathrm{M} \\
13.6\end{array}$ & 0.97 & Marder, $1973 b$ \\
\hline
\end{tabular}

* Values obtained through use of equations (1) and (3) are followed by P. Those obtained by direct measurement are followed by $\mathrm{M}$.

+ Measured at $30^{\circ} \mathrm{C}\left(T_{\mathrm{a}}\right)$, where $\dot{m}_{\mathrm{we}}$ shows relatively little temperature dependence. 
Table 6. Evaporative cooling by quiescent birds

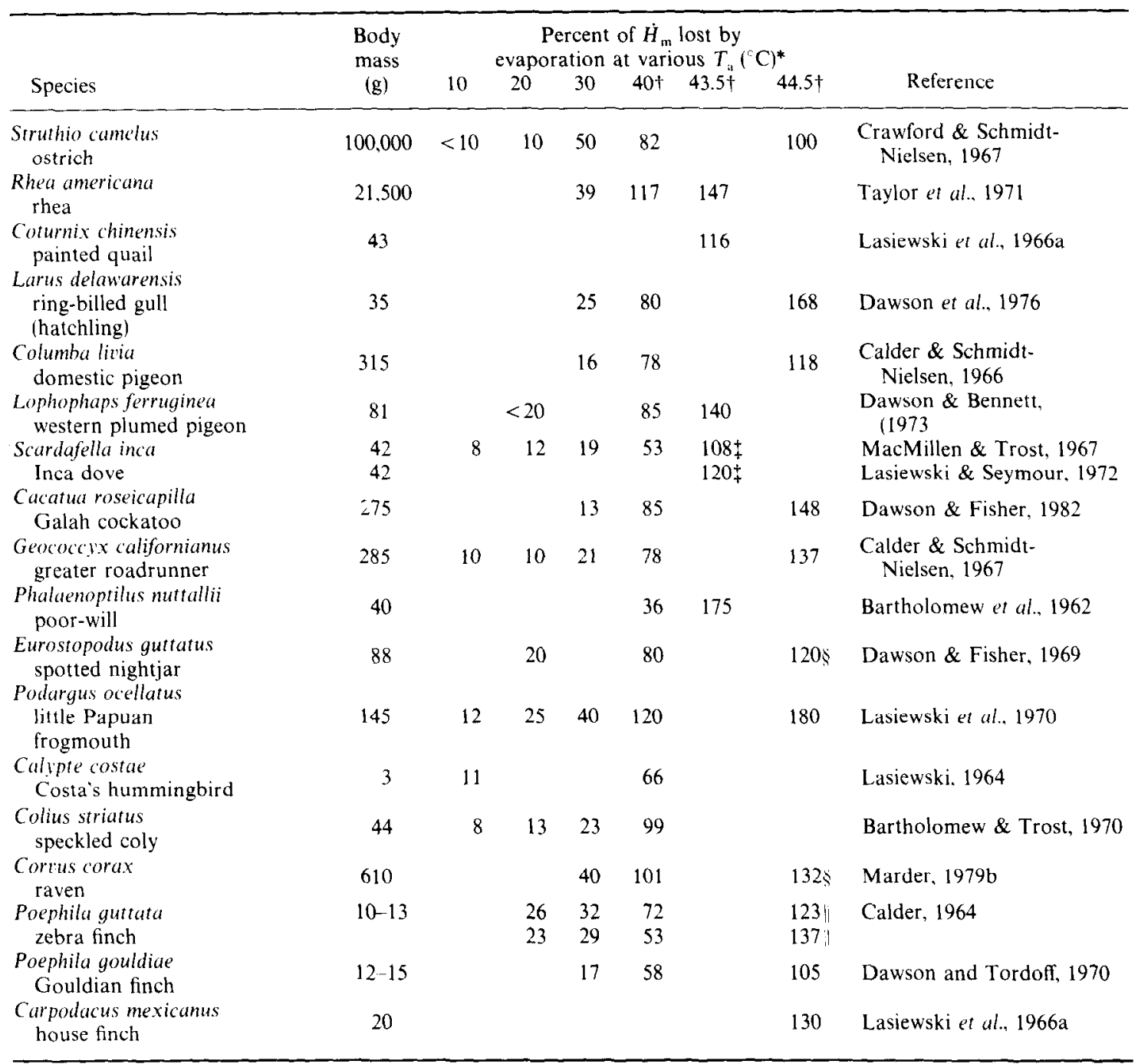

* $\dot{H}_{\mathrm{m}}=$ metabolic heat production; $T_{\mathrm{a}}=$ ambient temperature. Relative humidities vary among the studies.

$+ \pm 0.5 \mathrm{C}$.

$\ddagger$ Macmillen \& Trost's value was obtained at an aqueous vapor pressure of 23 torr $(34 \% \mathrm{RH})$, whereas Lasiewski \& Seymour's was obtained at 9-15 torr (13-24\% RH).

$\$$ At $52.8^{\circ} \mathrm{C}\left(T_{\mathrm{a}}\right)$ and 13 torr $(12 \% \mathrm{RH})$ aqueous vapor pressure, the spotted nightjar can evaporatively dissipate heat at a rate 3.1 times the rate of metabolic heat production. At $50^{\circ} \mathrm{C} T_{a}$ and an aqueous vapor pressure lower than 28 torr $(<30 \% \mathrm{RH})$, the raven can evaporatively dissipate heat at a rate 1.6 times metabolic heat production.

I' 123 and $137 \%$, pertain to hydrated and hydropenic individuals, respectively.

complexity of panting in birds, concluding that three basic patterns can be discerned in the normal expression of this activity (Phase I panting). Many species, including the mute swan (Cygnus olor), which they studied, decrease the tidal volume to a value near the dead space volume of the respiratory tract. The pigeon employs a compound pattern involving biphasic breathing in which a very fast and shallow component is superimposed upon a much slower and deeper breathing rhythm (Ramirez \& Bernstein, 1976; Bernstein \& Samaniego, 1981). Finally there is the pattern evident in the greater flamingo, Phoonicopterus ruher (Rech et al. 1979) which involves breathing at tidal volumes less than the dead space. At regular intervals this rhythm is interrupted by a short sequence of deeper breaths.
Tidal volume may rise above resting values under severe heat stress as Smith (1972) has shown for the domestic pigeon. This Phase II panting appears to represent an extreme response that Bech \& Johansen (1980b) regard as manifesting a breakdown in homeostasis associated with very high body temperatures. In the pigeon the rise of $V_{T}$ associated with the onset of phase II panting allows further increase in $\dot{V}^{\prime}$ up to $45.9^{\circ} \mathrm{C}$, even though $f$ reaches a maximum at $45.0^{\circ} \mathrm{C}$ and declines between there and $45.9 \mathrm{C}$.

The increased ventilation associated with panting exceeds metabolic requirements for gas exchange in a number of birds under severe heat stress and marked hypocapnia and respiratory alkalosis ensue (Calder \& SchmidtNielsen, 1966, 1968). A growing number of observations 
Table 7. Ratios of respiratory frequency $(f)$ and tidal volume $\left(V_{T}\right)$ of panting birds to resting* values

\begin{tabular}{lcccl}
\hline Species & $\begin{array}{c}f \\
\text { pant/rest }\end{array}$ & $\begin{array}{c}V_{\mathrm{r}} \\
\text { pant/rest }\end{array}$ & $\begin{array}{c}\dot{V} \\
\text { pant/rest }\end{array}$ & Reference \\
\hline $\begin{array}{l}\text { Columba livia } \\
\text { domestic pigeon }\end{array}$ & 22 & 0.48 & 10.6 & $\begin{array}{l}\text { Calder \& Schmidt-Nielsen, 1966; } \\
\text { Smith, 1972 }\end{array}$ \\
$\begin{array}{c}\text { Anus platyrhynchos } \\
\text { Pekin duck }\end{array}$ & 26 & 0.25 & 6.50 & Bouverot et al., 1974 \\
$\begin{array}{l}\text { Phoenicopterus ruber } \\
\text { greater flamingo }\end{array}$ & 23 & 0.15 & 3.45 & Bech et al., 1979 \\
$\begin{array}{c}\text { Cygnus olor } \\
\text { mute swan }\end{array}$ & 29 & 0.18 & $5.40+$ & Bech \& Johansen, 1980b \\
\hline
\end{tabular}

\author{
* Without heat stress. \\ $\uparrow$ This figure given by Beck $\&$ Johansen for this species although the product of the factors for $f$ and \\ $V_{\mathrm{T}}(29 \times 0.18)$ is actually 5.22 .
}

document the fact that major shifts in acid-base balance are not a universal accompaniment of panting activities. These pertain to the ostrich (Schmidt-Nielsen et al., 1969). Bedouin fowl (Marder et al., 1974); Pekin duck (Bouverot et al., 1974); Abdim's stork, Sphenorhynchus abdimii (Marder \& Arad, 1975); rock partridge, Alectoris chukar (Krausz et al.. 1977): greater flamingo (Bech et al., 1979); mute swan (Bech \& Johansen, 1980b); and domestic pigeon (Bernstein \& Samaniego, 1981). The various patterns described in connection with phase I panting appear adequate in at least some of these species to restrict ventilation of the exchange surfaces of the lungs sufficiently to resist hypocapnia without the invocation of special shunting arrangements. However, vascular connections do exist in the panting fowl that appear capable of shunting blood away from these exchange surfaces (Abdalla \& King, 1976).

Bech \& Johansen (1980b) suggest that the tendency of Calder \& Schmidt-Nielsen's $(1966,1968)$ birds to undergo marked hypocapnia and consequences might result from resorting to type II panting with its increased $V_{\mathrm{T}}$, in the face of severe heat stress. However, the ostrich (SchmidtNielsen et al., 1969), Abdim's stork (Marder et al., 1975), and rock partridge (Krausz et al., 1977) were also exposed to quite severe heat stress without any major shift in acidbase balance. It would be interesting to determine whether these birds, which inhabit very hot climates, are less prone to shift to type II panting than the birds studied by Calder \& Schmidt-Nielsen (1968).

\section{Water loss during locomotion}

Running and flight are vigorous activities which have a significant impact on evaporative water loss by birds, owing to the substantial increases in ventilation required for metabolic support. This impact may even extend beyond the bout of activity as birds initiate panting in ridding themselves of heat stored during flight (Butler et al., 1977; Butler \& Woakes, 1980). Knowledge of evaporation during running is based on Taylor et al.'s (1971) study of the rhea. Respiratory evaporation of this bird exercising at $25-43 \mathrm{C}\left(T_{\mathrm{a}}\right)$ varies with temperature. However, cutaneous evaporation remains relatively constant over this range (Table 1). The proportion of heat lost by evaporation at 35 and $43 . \mathrm{C}$ declines with running velocity, this trend being associated with increasing heat storage. In a run of $20 \mathrm{~min}$ at $10 \mathrm{~km} / \mathrm{hr}$, and $43^{\circ} \mathrm{C}\left(T_{\mathrm{a}}\right)$, only $27 \%$ of the heat produced was dissipated evaporatively. On the other hand, heat equivalent to $120 \%$ of heat production was dissipated by evaporation in rheas resting at $43 \mathrm{C}$, which stored substantially smaller quantities of heat than during running.

Energetics, breathing patterns, and heat dissipation of flying birds are reviewed by Berger \& Hart (1974). We should confine ourselves here mainly to questions of water balance during flight. Total evaporative water losses of nying budgerigars and evaporation relative to metabolism in these and representatives of two other species are presented in Table 8 . The rates for the buderigars exceed resting values by several fold and increase with ambient temperature. Information on total evaporative water loss for the three species included in Table 8 and on respiratory water loss for others (Berger et al., 1971; Berger \& Hart. 1972; and Bernstein, 1976) exceed the estimated concurrent production of metabolic water, except in three species studied at cool or cold ambient temperatures. In the starling the compensation point occurs at approx $7 \mathrm{C}$, below which production of water in oxidation would exceed evaporation. The tendency of birds to incur water deficits during flight at moderate and warm ambient temperatures seems paradoxical, given that most long distance migrants do not appear dehydrated when they arrive at their destinations (see Torre-Bueno, 1978, for discussion). Torre-Bueno (1978) suggests that migrating birds may remain in water balance by ascending to altitudes where temperatures are cool enough to foster a favorable relation between the gain of water by oxidation and by its loss by evaporation. He cites altitudes at which migrating birds have been observed flying, which are consistent with such a pattern.

\section{SUMMARY AND OVERVIEW}

Birds are well represented in all but the most unproductive environments on the earth's surface. However, they may even occupy some of these unpromising situations transiently during breeding or migration. As active, terrestrial homeotherms, birds must deal with evaporation as a significant component of their water budgets.

Contrary to earlier assumptions, losses by this process reflect cutaneous as well as respiratory evaporation in many species. In the absence of heat loading, countercurrent arrangements in the nasal passages allow for significant conservation of water and heat. However, most species still lose more water in evaporation than they produce in metabolism. Certain small birds, several of which are associated with arid situations, represent prominent exceptions to this. One factor in this appears to be an ability to restrict cutaneous losses of water.

With environmental heat loads, birds can resort to various behavioral and physiological devices that lessen the demand for evaporative cooling. Among the physiological stratagems is a widespread reliance on 
Table 8. Evaporation relative to metabolism in flying birds

\begin{tabular}{lcccl}
\hline Species & $\begin{array}{c}\text { Ambient } \\
\text { temp. } \\
\text { (C) }\end{array}$ & $\begin{array}{c}\text { Total } \\
\dot{m}_{\text {we }} \\
(\mathrm{mg} / \mathrm{g} / \mathrm{hr})\end{array}$ & $\dot{E} / \dot{M}$ & Reference \\
\hline Columba livia & & 9.9 & 0.10 & LeFebvre, 1964 \\
$\quad$ domestic pigeon $\dagger$ & & 20.4 & 0.11 & Tucker, 1968 \\
Melopsittacus undulatus & 19 & 25.0 & 0.14 & \\
$\quad$ budgerigar $\dagger$ & 30 & 63.9 & 0.35 & Torre-Bueno, 1978 \\
Sturnus vulgaris & 35 & & 0.07 & \\
$\quad$ starling & 5 & & 0.10 & \\
& 18 & & 0.16 & \\
\hline
\end{tabular}

\footnotetext{
* $\dot{E}$ and $\dot{M}$ (expressed in the same power units) represent evaporation and metabolism. respectively. At values of $\dot{E} / \dot{M}$ exceeding 0.064 , evaporation will exceed metabolic production of water when fat serves as the energy substrate. The figure rises to 0.081 when carbohydrate is used. Note that these ratios do not reflect the fraction of heat production $\left(\dot{H}_{\mathrm{m}}\right)$ dissipated by evaporative cooling, since approx $25 \%$ of $\dot{M}$ is directed toward the work of flight (see Tucker, 1968).

† Resting evaporative water loss by pigeons is $0.86 \mathrm{mg}(\mathrm{g} \cdot \mathrm{hr})^{-1}$ (Hart \& Roy, 1967) and the corresponding value for $E / M$ is 0.12 . Values for evaporative water loss by resting budgerigars range from 4.2 to $5.3 \mathrm{mg} / \mathrm{g} / \mathrm{hr}$ at 20 and $35^{\circ} \mathrm{C}$, respectively, according to Tucker (1968). The values of $\dot{E} / \dot{M}$ for these birds are $0.11\left(20^{\circ} \mathrm{C}\right)$ and $0.19\left(35^{\circ} \mathrm{C}\right)$.
}

controlled hyperthermia, which has a beneficial effect on water conservation. These animals can also initiate vigorous evaporative cooling through panting and, in certain cases, gular flutter. Cutaneous water loss can represent a significant component of heat defense, as well. Cases of unusually effective evaporative cooling typically reflect effortless panting, and perhaps, gular flutter, coupled with inherently low metabolic levels. Birds appear able to sustain panting activity for hours, despite progressive dehydration and, in certain instances, hypocapnia and respiratory alkalosis.

Apparently, all birds augment their evaporative cooling in response to heat loads. The ubiquitousness of this appears to reflect more the importance of coping with heat loads at the conclusion of bouts of running or flight, than any universal affinity for hot climates. The panting response is of interest from the standpoint of control, for thermoreceptors in the spinal cord play a dominant role, operating in conjunction with elements in the rostral brain stem and the skin.

Under most conditions, birds appear to incur water deficits through evaporation in flight, yet most migrants do not arrive at their destinations in a dehydrated state. The suggestion that individuals engaging in long distant flights ascend to elevations where cooler temperatures allow a more favorable relation between evaporation and metabolic production of water is an intriguing one consistent with some observations of flight patterns. It appears to provide another example of the role of hehavior in enhancing physiological capacity.

Acknowledgements-Preparation of this review was supported in part by a grant from the National Science Foundation (DEB 80-21389). The skilful assistance of Ms Sandra $\mathrm{K}$. Schaerer in typing the manuscript is gratefully acknowledged. I am grateful to Professor R. A. Suthers, Indiana University, Bloomington, for providing a copy of pertinent parts of R. M. Smith`s (1969) dissertation.

\section{REFERENCES}

AbDalla M. A. \& KING A. S. (1976) The functional anatomy of the bronchial circulation of the domestic fowl. $J$. Anat., London 121, 537-550.

Aulie A. (1971) Body temperatures in pigeons and budgerigars during sustained flight. Comp. Biochem. Physiol. 39A, 173-176.

Bartholomfw G. A. (1964) The roles of physiology and behaviour in the maintenance of homeostasis in the desert environment. Symp. Soc. exp. Biol. 18, 7-29.

BARTHOLOMEW G. A. (1966) The role of behavior in the temperature regulation of the masked booby. Condor $\mathbf{6 8}$, 523-535.

BARTHOLOMEW G. A. (1972) The water economy of seedeating birds that survive without drinking. Proc. $X V \mathrm{th}$ int. ornith. Congr. 237-254.

Bartholomew G. A. \& CADE T. J. (1963) The water economy of land birds. Auk 80, 504-539.

Bartholomew G. A. \& DAWSON W. R. (1953) Respiratory water loss in some birds of southwestern United States. Physiol. Zool. 26, 162-166.

Bartholomew G. A. \& Dawson W. R. (1954) Body temperature and water requirements in the mourning dove. Zenaidura macroura marginella. Ecology 35, 181-187.

Bartholomew G. A. \& Dawson W. R. (1958) Body temperatures in California and Gambel's quail. Auk 75, $150-156$.

Bartholomew G. A. \& Dawson W. R. (1979) Thermoregulatory behavior during incubation in Heermann's gulls. Physiol. Zool. 52, 422-437.

Bartholomew G. A. \& Trost C. H. (1970) Temperature regulation in the speckled mousebird, Colius striatus. Condor 72, 141-146.

Bartholomew G. A., Hudson J. W. \& Howell T. R. (1962) Body temperature, oxygen consumption, evaporative water loss, and heart rate in the poor-will. Condor 64, 117-125.

Bartholomew G. A., Lasiewski R. C. \& Crawrokd E. C., $J_{R}$ (1968) Patterns of panting and gular flutter in cormorants, pelicans, owls and doves. Condor 70, 31-34.

Baudinette R. V., Loveridge J. P., Wilson K. J., Mills C. D. \& SChmidt-Nielsen K. (1976) Heat loss from feet of herring gulls at rest and during flight. Am. J. Physiol. 230, 920-924 
Bech C. \& JohansEN K. (1980a) Ventilation and gas exchange in the mute swan, Cygnus olor. Respir. Physiol. 39, 285-295.

BECH C. \& JOHANSEN K. (1980b) Ventilatory and circulatory responses to hyperthermia in the mute swan (Cygnus olor). J. exp. Biol. 88, 195-204.

Bech C., Johansen K. \& Maloiy G. M. O. (1979) Ventilation and expired gas composition in the flamingo, Phoenicopterus ruber, during normal respiration and panting. Physiol. Zool. 52, 313-328.

Berger M. \& HaRT J. S. (1972) Die Atmung beim Kolibri Amazilia fimbriata wahrend des Schwirrfluges bei verschiedenen Umgebungstemperaten. J. comp. Physiol. 81, 363-380.

Berger M. \& Hart J. S. (1974) Physiology and energetics of flight. In Atian Biologi', Vol. iv (Edited by FARNER D. S. and KING J. R.), pp. 415-477. Academic Press, New York.

Berger M., HaRT J. S. \& RoY O. Z. (1971) Respiratory water and heat loss of the black duck during flight at different ambient temperatures. Can. J. Zool, 49 , $767-774$.

BERNSTEIN M. H. (1971) Cutaneous and respiratory evaporation in the painted quail, Excalfactoria chinensis, during ontogeny of thermoregulation. Comp. Biochem. Physiol. 38A, 611-617.

Bernstein M. H. (1974) Vascular responses and foot temperature in pigeons. Am. J. Physiol. 226, 1350-1355.

BERNSTEIN M. H. (1976) Ventilation and respiratory evaporation in the flying crow, Corrus ossifruyus. Respir. Physiol. 26, 371-382

Bernstein M. H. \& Samaniego F. C. (1981) Ventilation and acid-base status during thermal panting in pigeons (Columba livia). Physiol. Zool. 54, 303-315.

BerNSTEIN M. H. \& SCHMidT-NielsEN K. (1974) Ventilation and oxygen extraction in the crow. Respir. Physiol. 21, 393-401.

Bernstein M. H., Hudson D. M., Stearns, J. M. \& Hoyt R. W. (1977) Measurement of evaporative water loss in small animals by dew-point hygrometry. $J$. appl. Physiol.: Environ. Exercise Physiol. 43, 382-385.

Bernstein M. H., Sandoval I., Curtis M. B. \& Hudson D. M. (1979a) Brain temperature in pigeons: effects of anterior respiratory bypass. J. comp. Phisiol. 129B. $115-118$.

Bernstein M. H., Curtis M. B. \& Hudson D. M. (1979b) Independence of brain and body temperatures in flying American kestrels, Falco sparterius. Am. J. Physiol. 237, R58-R62.

Bouverot B., IIILdwein G. \& Legoff D. (1974) Evaporative water loss, respiratory pattern, gas exchange and acid-base balance during thermal panting in Pekin ducks exposed to moderate heat. Respir. Physiol. 21, 255-209.

Bropy S. (1945) Bioenergetics and Growth. Reinhold. New York.

Butler P. J. \& Woakes A. J. (1980) Heart rate, respiratory frequency and wing beat frequency of free flying barnacle geese Branta leucopsis. J. exp. Biol. 85, 213-226.

BUTleR P. J., WEST N. H. \& JONES D. R. (1977) Respiratory and cardiovascular responses of the pigeon to sustained level flight in a wind-tunnel. $J$. exp. Biol. 71, 7-26.

CADE T. J. \& Bartholomew G. A. (1959) Seawater and salt utilization by savannah sparrows. Physiol. Zool. 32, 230-238.

CaDe T. J. \& DYBas J. A., JR (1962) Water economy of the budgerygah. Auk 79, 345-364.

CADE T. J., ToBin C. A. \& Gold A. (1965) Water economy and metabolism of two estrildine finches. Physiol. Zool 38, 9-33.

Calder W. A. (1964) Gaseous metabolism and water relations of the zebra finch, Taeniopygia castanotis. Physiol. Zool. 37, 400-413.
Calder W. A. \& King J. R. (1974) Thermal and caloric relations of birds. In Avian Biologi: Vol. IV (Edited by FARNER D. S. \& KING J. R.), pp. 259-413. Academic Press, New York.

Calder W. A. JR \& Schmidt-Nielsen K. (1966) Evaporative cooling and respiratory alkalosis in the pigeon. Proc. natn Acad. Sci. U.S.A. 55, 750-756.

Calder W. A. \& S(hmidt-Nielsen K. (1967) Temperature regulation and evaporation in the pigeon and the roadrunner. Am. J. Physiol. 213, 883-889.

CAlder W. A. \& Schmidt-Nielsen K. (1968) Panting and blood carbon dioxide in birds. Am. J. Physiol. 215. 477-482.

CAREY C. (1980) Introduction to the symposium: physiology of the avian egg. Am. Zool. 20, 325-327.

Crawford E. C., JR (1962) Mechanical aspects of panting in dogs. J. appl. Physiol. 17, 249-251.

Crawford E. C., JR \& KamPE G. (1971) Resonant panting in pigeons. Comp. Biochem. Physiol 40, 549-552.

Crawford E. C., JR \& Lasiewski R. C. (1968) Oxygen consumption and respiratory evaporation of the emu and rhea. Condor 70, 333-339.

Crawford E. C.. JR \& Schmidt-Niflsen K. (1967) Temperature regulation and evaporative cooling in the ostrich. Am. J. Physiol. 212, 347-353.

CunNinghaM K. G. (1982) Relationship between metabolism and lifestyle in the loggerhead shrike. Physiol. Zool. (in press).

DAWson W. R. (1954) Temperature regulation and water requirements of the brown and Abert towhees, Pipilo fuscus and Pipilo aberti. Univ. Calif. Publ. Zool. 59, $81-124$.

Dawson W. R. (1975) Avian physiology. Ann. Ret. Phisiol. 37, 441-465.

DAwSON W. R. (1976) Physiological and behavioural adjustments of birds to heat and aridity. Proc, $16 \mathrm{th}$ int ornith. Conyr. 455-467.

Dawson W. R. (1981) Adjustments of Australian birds to thermal conditions and water scarcity in arid zones. In Ecological Biogeography of Australia (Edited by KFAST A. O.), pp. 1651-1674. W. Junk, The Hague.

DAwson W. R. \& Bartholomew G. A. (1968) Temperature regulation and water economy of desert birds. In Desert Biology, Vol. 1 (Edited by BROWN G. W. JR), pp. 357-394. Academic Press, New York

DAwsON W. R. \& BENNETT A. F. (1973) Roles of metabolic level and temperature regulation in the adjustment of western plumed pigeons (Lophophaps ferruginea) to desert conditions. Comp. Biochem. Physiol. 44A, 249266.

Dawson W. R. \& Fisher C. D. (1969) Responses to temperature by the spotted nightjar (Eurostopodus guttatus). Condor 71, 49-53

Dawson W. R. \& Fisher C. D. (1982) Observations on the temperature regulation and water economy of the galah (Cacatua roseicapilla). Comp. Biochem. Physiol. (in press).

Dawson W. R. \& Hudson J. W. (1970) Birds. In Comparative Physiology of Thermoregulation, Vol. 1 (Edited by WhitTow G. C.). pp. 223-310. Academic Press, New York.

Dawson W. R. \& Schmidt-Nielsen K. (1964) Terrestrial animals in dry heat: desert birds. In Handbook of Physiology. Sect. 4 Environment (Edited by Dil. D. B.). pp. 481-492. Am. Physiol. Soc. Washington, D.C.

Dawson W. R. \& TORDOFF H. B. (1970) Unpublished data cited in Dawson and Hudson (1970).

Dawson W. R., Bennett A. F. \& Hudson J. W. (1976) Metabolism and thermoregulation in hatchling ringbilled gulls. Condor 78, 49-60.

DaWSON W. R., CaReY C., ADKISSON C. S. \& OHMART R. D. (1979) Responses of Brewer's and chipping sparrows to water restriction. Physiol. Zool. 52, 529-541.

EDMonds V. W. (1968) Survival of the cutthroat finch 
(Amadina fasciata) under desert conditions without water. Auk 85, 326-328.

FARNer D. S. (1956) Body temperature of the fairy prion (Pachyptila turtur) in flight and at rest. J. appl. Physiol. 8, $546-548$

HaRT J. S. \& RoY O. Z. (1967) Temperature regulation during flight in pigeons. Am. $J$. Physiol. 213, 1311-1316.

I HOWELL T. R. \& BAR Tholomew G. A. (1961) Temperature regulation in Laysan and black-footed albatrosses. Condor 63, 185-197.

Howel. T. R. \& Barthol omfw G. A. (1962) Temperature regulation in the red-tailed tropic bird and the redfooted booby. Condor 64, 6-18.

HUDSON D. M. \& BERNSTEIN M. H. (1981) Temperature regulation and heat balance in flying white-necked ravens, Corvus cryptoleucus. J. exp. Biol. 90, 267-281.

Hudson J. W., DAWson W. R. \& HILl R. W. (1974) Growth and development of temperature regulation in nestling cattle egrets. Comp. Biochem. Physiol. 49A, 717-741.

IIUTCHinson J. C. D. (1954) Heat regulation in birds. In Progress in the Physiology of Farm Animals, Vol. I (Edited by Hammond J.), pp. 299-362. Butterworth, London.

KendeIGH S. C. (1944) Effect of air temperature on the rate of energy metabolism in the English sparrow. J. exp. Zool. 96, 1-16.

Kilgore D. L., JR, Bernstein M. H. \& Schmidt-Nielsen K. (1973) Brain temperature in a large bird, the rhea. Am. J. Physiol. 225, 739-742.

Kilgore D. L., JR, BeRNSTEIN M. H. \& HUdSON D. M (1976) Brain temperatures in birds. J. comp. Physiol. 110 , 209-215.

Kilgorf D. L., JR, Boggs D. F. \& Birchard G. F. (1979) Role of Rete mirabile opthalmicum in maintaining the body-to-brain temperature difference in pigeons. $J$. comp Physiol. 129, 119-122.

KING J. R. \& FaRner D. S. (1964) Terrestrial animals in humid heat: birds. In Handbook of Physiology, Sect. 4 Environment (Edited by DILL D. B.), pp. 603-624. Am. Physiol., Washington, D.C.

Krausz S., Bernstein R. \& Marder J. (1977) The acid base balance of the rock partridge (Alectoris chukar) exposed to high ambient temperatures. Comp. Biochem. Physiol. 57A, 245-247.

LACEY R. A., JR (1965) Mechanical Determinants of Panting Frequency in the Domestic Fowl. M.A. Thesis, University of California, Davis.

LACEY R. A.. JR \& Burger R. E. (1972) Personal communication cited in Lasiewski (1972).

Lasiewski R. C. (1964) Body temperatures, heart and breathing rate, and evaporative water loss in humming. birds. Physiol. Zool. 37, 212-223.

LAsiewski R. C. (1969) Physiological responses to heat stress in the poor-will. Am. J. Physiol. 217, 1504-1509.

LASIEWSKI R. C. (1972) Respiratory function in birds. In Avian Biology, Vol. II (Edited by FarNER D. S. \& KING J. R.), pp. 287-342. Academic Press. New York.

LASIEWSKi R. C. \& Bartholomew G. A. (1966) Evaporative cooling in the poor-will and tawny frogmouth Condor 68, 253-262.

LASiewski R. C. \& Dawson W. R. (1964) Physiological responses to temperature in the common nighthawk Condor 66, 477-490.

LASIEWSKI R. C. \& DAWSON W. R. (1967) A re-examination of the relation between standard metabolic rate and body weight in birds. Condor 69, 13-23.

LASIE.WSKI R. C. \& Seymour R. S. (1972) Thermoregulatory responses to heat stress in four species of birds weighing approximately 40 grams. Physiol. Zool. 45, 106-118.

LASIEWSK1 R. C. \& SNYDER G. K. (1969) Responses to high temperature in nestling double-crested and pelagic cormorants. Auk 86, 529-540
Lasiewski R. C., Acosta A. L. \& Bernstein M. H. (1966a) Evaporative water loss in birds-1. Characteristics of the open flow method of determination, and their relation to estimates of thermoregulatory ability. Comp. Biochem. Physiol. 19, 445-457.

Lasiewski R. C., Acosta A. L. \& Bernstein M. H. (1966b) Evaporative water loss in birds-II. A modified method for determination by direct weighing. Comp. Biochem. Physiol. 19, 459-470.

Lasiewski R. C., Dawson W. R. \& Bartholomew G. A (1970) Temperature regulation in the little Papuan frogmouth, Podargus ocellatus. Condor 72, 332-338.

Lasiewski R. C., Bernstein M. H. \& OHMaRT R. D. (1971) Cutaneous water loss in the roadrunner and the poorwill. Condor 73, $470-472$

LeE P. \& SChmidt-NIELSEN K. (1971) Respiratory and cutaneous evaporation in the zebra finch: effect on water balance. Am. J. Physiol. 220, 1598-1605.

LeFeBvre E. A. (1964) The use of $\mathrm{D}_{2} \mathrm{O}^{18}$ for measuring energy metabolism in Columba livia at rest and in flight. Auk 81, 403-416.

Lindaren E. (1973) Studies on the Ecology and Physiology of Three Species of Grassparrots. Ph.D. Thesis, Univ. of Western Australia, Nedlands.

Macmillen R. E. \& Trost C. H. (1967) Thermoregulation and water loss in the Inca dove. Comp. Biochem. Physiol. 20, 263-273.

MCNABB F. M. A. \& MCNABB R. A. (1977) Skin and plumage changes during the development of thermoregulatory ability in Japanese quail chicks. Comp. Biochem. Physiol 58A, 163-166.

MADSEN H. (1930) Quelques remarques sur la cause pourquoi les grand oiseux au Soudan planent si haut au milieu de la journée. Videnskab. Medd. Dansk. Naturhist. Forh. Kobenhaven 8, 301-303.

MARDER J. (1973a) Temperature regulation in the Bedouin fowl. Physiol Zool. 46, 208-217.

MARDER J. (1973b) Body temperature regulation in the brown-necked raven (Corvus corax ruficollis)-I. Metabolic rate, evaporative water loss and body temperature of the raven exposed to heat stress. Comp. Biochem. Physiol. 45A, 421-430.

MARDER J. \& ARAD Z. (1975) The acid base balance of Abdim's stork (Sphenorhynchus abdimii) during thermal panting. Comp. Biochem. Physiol. 51A, 887-889.

Marder J., ARAD Z. \& GafNi M. (1974) The effect of high ambient temperature on acid-base balance of panting Bedouin fowl (Gallus domesticus). Physiol. Zool. 47, 180-189.

Menuam B. \& Richards S. A. (1975) Observation on the sites of respiratory evaporation in the fowl during thermal panting. Respir. Physiol. 25, 39-52.

MOLDENhaUer R. R. \& TAYlor P. G. (1973) Energy intake by hydropenic chipping sparrows (Spizella passerina passerina) maintained on different diets. Condor 75, $439-445$.

MURRISH D. E. (1973) Respiratory heat and water exchange in penguins. Respir. Physiol. 19, 262-270.

NFCKER R. (1975) Temperature-sensitive ascending neurons in the spinal cord of pigeons. Pflüger's Arch. 353, 275-286.

Necker R. \& Rautenberg W. (1975) Effect of spinal deafferentation on temperature regulation and spinal thermosensitivity in pigeons. Pflüger's Arch. 360, 287-299.

Neumann R. I., Hudson J. W. \& Hock R. J. (1968) Body temperatures, Table 59, Part II. Birds. In Metabolism (Edited by Altman P. L. \& DitTmer D. S.), pp. 334- 343. Fedn. Am. Soc. exp. Biol., Bethesda.

OHMART R. D. \& SMITH E. L. (1970) Use of sodium chloride solutions by the Brewer's and tree sparrows. Auk $\mathbf{8 7}$, 329-334.

Ohmart R. D. \& Smith E. L. (1971) Water deprivation and 
use of sodium chloride by vesper sparrows (Pooecetes gramineus). Condor 73, $364-366$.

OHMart R. D., ChapMan T. E. \& MCFarland L. Z. (1970) Water turnover in roadrunners under different environmental conditions. Auk 87, 787-793.

Ramirez J. M. \& BernsterN M. H. (1976) Compound ventilation during thermal panting in pigeons: a possible mechanism for minimizing hypocapnic alkalosis. Fedn. Prod. Fedn. Am. Socs. exp. Biol. 35, 2562-2565.

RAUTENBERG W. (1969) Die Bedeutung der zentral nervosen Thermosensitivat fur die Temperaturregulation der Taube. Z. vergl. Phvsiol. 62, 235-266.

RAUTENBERG W. (1971) The influence of the skin temperature on the thermoregulatory system of pigeons. $J$. Physiol. (Paris) 63, 396-398.

Rautenbero W. Necker R. \& May B. (1972) Thermoregulatory responses of the pigeon to changes of the brain and the spinal cord temperatures. Pfluger's Arch. $338,31-42$.

Rautenberg W., May B., Necker R. \& Rosner G. (1978) Control of panting by thermosensitive spinal neurons in birds. In Respiratory Function in Birds, Adult and Embryonic (Edited by PIIPER J.), pp. 204 210. Springer, Berlin.

Rautenberg W., May B. \& Arabin G. (1980) Behavioral and autonomic temperature regulation in competition with food intake and water balance of pigeons. Pflüger's Arch. 384, 253-260.

RICHARDS S. A. (1968) Vagal control of panting in mammals and birds. J. Physiol., London 199, 89-101.

Richards S. A. (1970a) The biology and comparative physiology of thermal panting. Biol. Rev. 45, 223-264.

RichardS S. A. (1970b) The role of hypothalamic temperature in the control of panting in the chicken exposed to heat. $J$. Physiol., London 211, 341-358.

Richards S. A. (1971a) The significance of changes in the temperature of the skin and body core of the chicken in the regulation of heat loss. J. Physiol., London 216, 1-10.

RICHARDS S. A. (1971b) Brain stem control of polypnoea in the chicken and pigeon. Respir. Physiol. 11, 315-326.

Richards A. S. (1975) Thermal homeostasis in birds. Symp. zool. Soc: Lond. No. 35, pp. 65-96.

Richards S. A. (1976) Behavioural temperature regulation in the fowl. $J$. Physiol., London 258, 122P-123P.

RICHARDS S. A. \& Avery P. (1978) Central nervous mechanisms regulating thermal panting. In Respiratory Function in Birds, Adult and Embryonic (Edited by PIPER J.) pp. 196-203. Springer. Berlin.

ROSNER G. (1977) Response of hypothalamic neurons to thermal stimulation of spinal cord and skin in pigeons. Pfiüger's Arch. 338, R29.

SAAFELD E. vON (1936) Untersuchungen über das Hacheln bei Tauben. Z. vergl. Physiol. 23, 727-743.

Salt G. W. (1964) Respiratory evaporation in birds. Biol. Rev. 39, 113-136.

SChARdien B. J. \& JaCkson J. A. (1979) Belly-soaking as a thermoregulatory mechanism in nesting killdeers. $A u k$ 96, 604-606.

SCHMIDT I. (1976) Effect of central thermal stimulation on the thermoregulatory behavior of the pigeon. Pfiiger's Arch. 363, 271-272.

Schmid I. (1978) Interactions of behavioral and autonomic thermoregulation in heat stressed pigeons Pflüger's Arch. 374, 47-55.

SCHMIDT I. \& RAUTENBERG W. (1975) Instrumental thermoregulatory behavior in pigeons. $J$, comp. Physiol. 101, $225-235$

Schmidt-Nielsen K. (1964) Desert Animals. Clarendon Press, Oxford.

SChMidt-NielSEN K., Kanwisher J., Lasiewski R. C.,
COHN J. E. \& BRETz W. L. (1969) Temperature regulation and respiration in the ostrich. Condor 71, 341-352. SCHMidT-NiELSEN K. HaINSWORTH F. R. \& MURrish D. E (1970) Counter-current heat exchange in the respiratory passages: effect on heat and water balance, Respir. Physiol. 9, 263-276.

Scott N. R. \& Tienhoven A. van (1971) Simultaneous measurement of hypothalamic and body temperatures and heart rate in poultry. Trans. Am. Soc. agr. Engng 14 , 1027-1033.

Seymour R. S. (1972) Convective heat transfer in the respiratory systems of panting animals. J. theor. Biol, 35, 119-127.

Simon E. Hammel H. T. \& OKsche A. (1977) Thermosensitivity of single units in the hypothalamus of the conscious Pekin duck. J. Neurobiol. 8, 523-535.

Simon-Oppermann C. Simon E., Jessen C. \& Hammel H. T. (1978) Hypothalamic thermosensitivity in conscious Pekin ducks. Am. J. Physiol. 235, R130-R140.

Smith R. M. (1969) Cardiovascular, Respiratory, Temperature and Evaporative Water Loss Responses of Pigcons to Varying Degrees of Heat Stress. Ph.D. Thesis, Indiana University, Bloomington.

SMith R. M. (1972) Circulation, respiratory volumes and temperature regulation of the pigeon in dry and humid heat. Comp. Biochem. Physiol 43A, 477-490

Smyth M. \& Bartholomew G. A. (1966) The water economy of the black-throated sparrow and the rock wren. Condor 68, 447-458.

STEEN I. \& STEEN J. B. (1965) The importance of the legs in the thermoregulation of birds. Actu physiol. scand. 63, 285-291.

Taylor C. R., Dmiel R. Fedak M. \& Schmidt-Nielsen K. (1971) Energetic cost of ruming and heat balance in a large bird, the thea. Am. J. Physiol 221, 597-601

TORRE-BUENO J. R. (1976) Temperature regulation and heat dissipation during flight in birds. $f$. exp. Biol. 65 , $471-482$.

TORRE-BUENO J. R. (1978) Evaporative cooling and water balance during flight in birds. $J$. exp. Biol. 75, 231-236.

Trost C. H. (1972) Adaptations of horned larks Eremophila alpestris to hot environments. Auk 89, 506-527.

TUCKER V. A. (1968) Respiratory exchange and evaporative water loss in the Hying budgerigar. $J$. exp. Biol. 48, 67-87.

Weathers W. W. (1972) Thermal panting in domestic pigeons, Columba livia, and the barn owl. Tyto alha. $J$. comp. Physiol. 79, 79-84.

Weathers W. W. (1981) Physiological thermoregulation in heat stressed birds: consequences of body size. Physiol Zool. 64, 345-361.

Weathers W. W. \& SChoenbaechler D. C. (1976) Contribution of gular flutter to evaporative cooling in Japanese quail. J. appl. Physiol. 40, 521-524.

WILLOUGHBY E. J. (1968) Water economy of the Stark's lark and grey-backed finch-lark from the Namib Desert of South West Africa. Comp. Biochem. Physiol. 27, 723-745.

Willoughay E. J. (1969) Evaporative water loss of a small xerophilous finch, Lonchura malahariea. Comp. Biochem. Physiol. 28, 655-664.

WILLovghBY E. J. \& CADE T. J. (1967) Drinking habits of birds in the central Namib Desert of South West Africa. Sci. Pupers Namib Desert Re's. Station, No. 31, pp. 1-35.

Wingstrand K. G. \& MUNK O. (1965) The pecten oculi of the pigeon with particular regard to its function. Biol. Skrifter 14, 1-64.

Yeates N. T. M., LeE D. H. K. \& Hindos H. J. B. (1941) Reactions of domestic fowls to hot atmospheres. Proc, $R$. Soc. Queensland 53, 105-128. 